\title{
A Colônia Japonesa de Ivoti - impressões de uma jovem pesquisadora
}

\author{
Caroline Stumpf Buaes \\ MESTRANDA PPGEDU-UFRGS
}

Nos meses de julho e agosto de 2002, nosso grupo de pesquisa realizou várias visitas à Colônia Japonesa de Ivot - RS, no contexto da pesquisa Imigtação e Envelhecimento - processos de aprendizagem cultural. As linhas que seguem revelam minhas expectativas e impressóes antes e durante estas visitas.

Muitas foram as fantasias idealizadas por uma pesquisadora brasileira, de origem libanesa, alemã e italiana, acerca de uma Colônia Japonesa localizada em Ivoti, cidade gaúcha de colonização alemã. Essa pequena frase já revela que estanos nos referindo a uma situação de mistura étnica e cultural.

Confesso que imaginava um lugar com uma arquitetura típica de filmes orientais, com casas de fachadas rebuscadas de delicados desenhos e com sinos tocando a cada rajada de vento. Para minha surpresa, ao chegar na Colônia, nada a diferenciava de uma colônia "não japonesa", de qualquer comunidade rural do Rio Grande do Sul. Foi ao longo do desenvolvimento da pesquisa que percebi alguns hábitos diferentes e típicos da cultura japonesa, no entanto, estes pareciam mais testritos ao domínio privado das famílias visitadas, não evidenciados na parte externa de suas casas.

Moram na Colônia Japonesa de Ivoti cerca de 40 famílias que desenvolvem atividades agrícolas baseadas, atualmente, no plantio de frutas, mudas $\mathrm{e}$ flores. Nas propriedades, o que mais avistávamos eram árvotes de laranja e estufas de mudas e flores. As casas são de alvenaria, algumas possuem jardim em sua volta, todas tem como guardiões barulhentos cachorros. Algumas vezes, entramos dentro das residências e observamos que seus móveis não eram diferentes dos que estamos costumados a ver nas casas que freqüentamos.

Determinados hábitos revelaram que há diferenças culturais, apesar de tantas semelhanças, entre a Colônia Japonesá e outras comunidades turais gaúchas. Algumas tradições petcebidas são conhecidas por nós brasileiros, dentre elas, destaco: a maneira de cumprimentar uns aos outros inclinando levemente a cabeça e com pouco contato, sem beijos e abtaços; o costume de tirar os sapatos ao entrar em casa; o jeito de falar devagar; o hábito de tomar o chá-verde. No entanto, singularidades foram observadas, como a forma 
de estender roupas no varal sem prendedores, mas com uma espécie de cabide madeira que possuía pernas, pois assim a roupa ficava esticada como se estivesse em um coxpo humano.

Lembro-me ainda do chá-verde, que tomamos na companhia de um casal de imigrantes, sendo servido com balinhas de café de uma marca conhecida em nosso estado e que nada lembra a cultura oriental. Foi nesse cenário de novidades, de hábitos conhecidos e de misturas de elementos culturais diferentes que fomos construindo nossos contatos e coletando os dados da pesquisa Imigração e Envelhecimento - processos de aprendizagem cultural.

Os contatos com moradores da Colônia Japonesa de Ivoti foram possibilitados pela Prof. Tomoko Kimura Gaudioso, do Instituto de Letras da Universidade Federal do Rio Grande do Sul. Ela veio do Japão em 1961 e, em função disso, conhecia alguns moradores da colônia, o que facilitou a aproximação dos ourros pesquisadores aos sujeitos da pesquisa, principalmente, quando era necessário o uso da língua japonesa para a comunicação.

Conhecemos o presidente da Associação da Colônia Japonesa na primeira visita à colônia. A partir desse contato, ficamos sabendo o número aproximado de famílias que habitam o local e também alguns hábitos dos moradores no que se refere à vida social, aos encontros na associação para jogos e reuniões.

Para que pudéssemos atingir todos os objetivos da pesquisa, era de fundamental importância entrevistarmos o maior número possível de imigrantes. Para tanto, foi necessário visitarmos suas casas para poder conhecê-los, apresentar a pesquisa e, por fim, realizar as entrevistas. A procura das casas dos moradores foi facilitada por um mapa desenhado por uma moradora em uma foll a de papel, que nos guiava e orientava na descoberta dos caminhos da Colonia.

Quando chegávamos nas propriedades, o primeiro contato com os moradores era feito unicamente pela Prof $f^{2}$. Tomoko que descia sozinha do carto e batia em suas casas. Enquanto isso, o restante do grupo, dividido em dois carros, torcia para que aceitassem conversar conosco. Após aptesentar a pesquisa e o morador concordar em ser entrevistado, o restante do grupo descia dos carros. Em seguida, o Prof. Johannes Doll era apresentado como professor e pesquisador da UFRGS, o que the conferia uma certa confiabilidade. Os outros pesquisadores ficavam próximos e atentos à situação da entrevista, pois todos os detalhes deveriam ser observados, já que são reveladores de hábitos e maneiras de ser que muitas vezes não são expressos pelas palavras.

Com o passar das idas a campo, o grupo foi tornando-se mais familiarizado com a colônia e seus moradores, porém a atenção dos pesquisadores permanecia sempre focalizada sobre questões que podem auxiliar ou prejudicar a coleta de dados, buscando-se sempre priorizar o respeito pela cultura japonesa.

\section{Um dia em Ivoti}

Um dia em Ivoti inicia por volta de 8 horas da manhã de sábado, com o encontro dos pesquisadores na Faculdade de Direito da UFGRS para tomarmos o rumo da cidade. Geralmente, iam sete pesquisadores em dois carros. 
Chegando na Colônia Japonesa, íamos diretamente para a sede da Associação para verificar se algo estava acontecendo como reuniöes, jogos, encontros. Se não percebíamos nenhum movimento na Associação, definíamos que casas iríamos visitar para realizar as entrevistas.

Certa vez, chegamos lá e tivemos a oportunidade de assistir a um festival de folclore - ENGGEIKAI que reuniu imigrantes japoneses que vivem em outras regiões do Rio Grande do Sul. Crianças, adultos e idosos apresentatam peças de teatro, executaram instrumentos musicais, exibiram danças e declamaram poesias típicas. Nesse dia, além de observar as apresenrações artísticas e realizar diversas entrevistas, tivemos um momento de bastante integração à festa e aos moradores da colônia participando de uma rifa, na qual fui sorteada com um brinde que guardo como lembrança da pesquisa.

Por volta das 13 horas, era feita a pausa para o almoço na cidade de Ivoti em um restaurante que tornou-se bastante conhecido pelo grupo. Após o almoço, em frente ao restaurante, juntávamos mesas e cadeiras em forma de círculo e sentávamos para fazer uma breve reunião, em que os preciosos deralhes observados por cada pesquisador eram discutidos. Depois de anotar tudo o que havia acontecido durante a manhã, era a hora de programar o restante da tarde e retornar à colônia. Geralmente, por volta de 15 horas, retornávamos em busca de mais visiras e entrevistas.

Pesquisas de campo, como esta na Colônia Japonesa de Ivoti, proporcionam conhecimentos, interação pesquisador-pesquisado e observações riquíssimas dos hábitos dos sujeitos, pois em certos momentos entrávamos em suas casas para usar o banheiro ou tomar um copo de água, ou mais...

Certo sábado fomos recebidos pelo senhor mais velho da colônia em sua casa, sentamos descalços nos sofás de sua sala e desfrutamos de um momento incrível tomando chá-verde e ouvindo sua história de vida e de sua chegada ao Brasil. Tudo nos foi contado em japonês e traduzido no mesmo momento pela Prof ${ }^{a}$. Tomoko. Esse, sem dúvida, foi o momento de maior estranhamento e encantamento vivenciado por mim. Entramos na sala sem sapatos, a temperatura estava agradável no interior da casa, pois fora fazia uma tarde muiro quente. $\mathrm{O}$ tom de voz do senhor era tranqüilo, quase uma canção em japonês para meus ouvidos. Fui me sentindo telaxada e fascinada ohservando os detalhes daquela casa, que internamente guardava muito da cultura japonesa. Em uma cristaleira havia uma série de artesanato e bonecos típicos. Meu estado de fascínio foi elevado quando a senhora japonesa nos serviu um delicioso chá-verde em louças de característica japonesa.

Essa sensação de estranhamento surgiu justamente na casa do senhor mais velho, porque me parece que a primeira geração de imigrantes, "os isseis", preserva traços mais diferentes da cultura do que os imigrantes da segunda geração, "os nisseis", que me parecem mais "abrasileirados". São esses detalhes que a gente vê, sente e toca, que não são falados pelos sujeitos de uma pesquisa, que tornatam essa experiência de pesquisa de campo tão rica e importante para minha formação de pesquisadora.

O término das idas para o campo se dava por volta das 19 horas, quando chegava em minha casa. Sentia-me cansada, mas feliz com a quantidade de dados obtidos e, acima de tudo, pelas experiências vivenciadas na Colônia Japonesa. 